\title{
Low Temperature Superplastic Flow of Yttria Stabilized Tetragonal Zirconia Polycrystals
}

\author{
M. M. R. Boutz, A. J. A. Winnubst, * A. J. Burggraal'

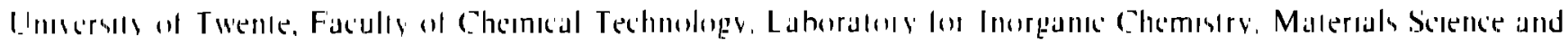

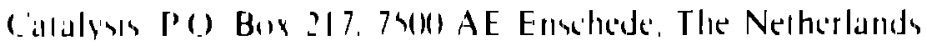

$\&$

\section{Niller, $\nleftarrow$ C. Call ryş}

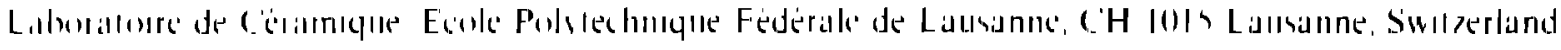

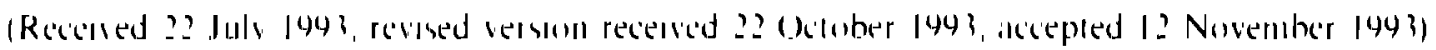

\begin{abstract}

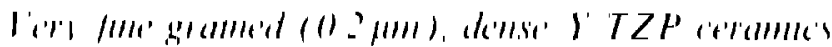

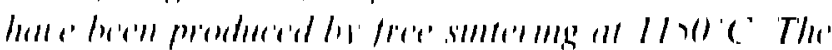

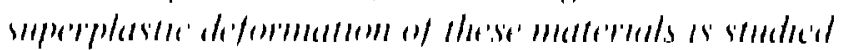

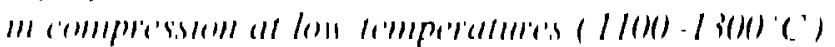

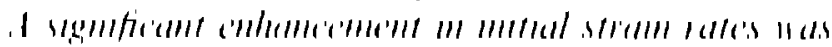

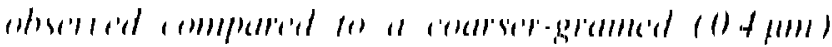

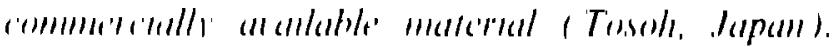

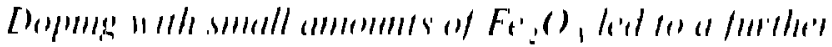

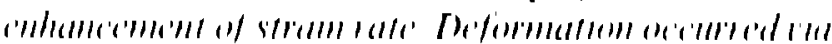

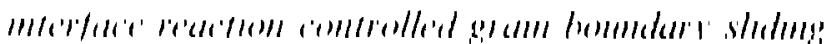

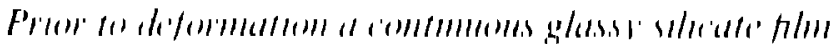

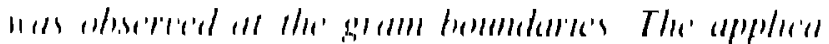

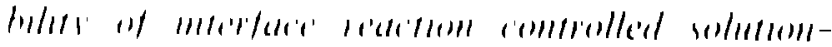

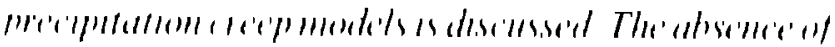

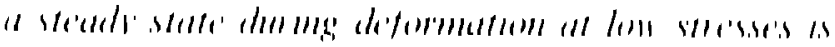

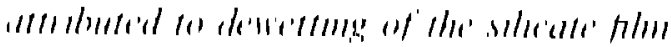

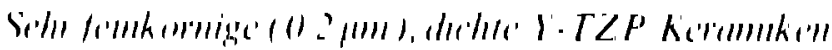

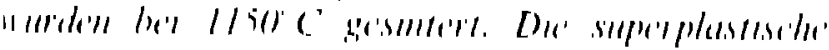

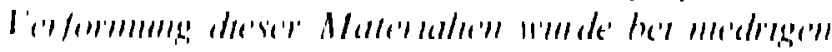

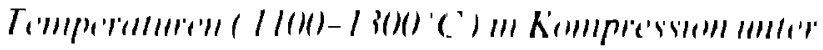

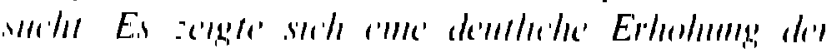

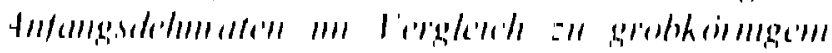

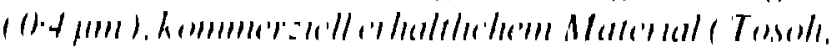

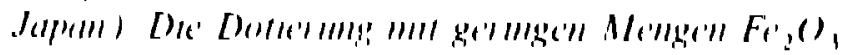

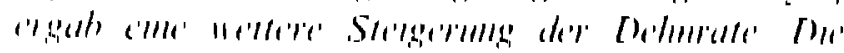

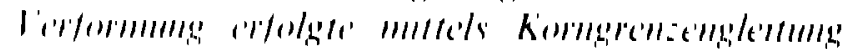

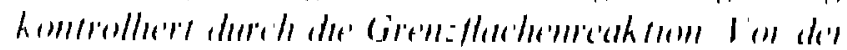

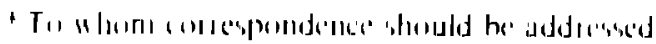

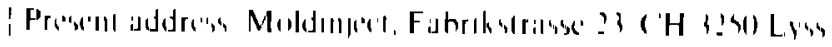
sindserlings

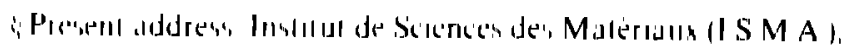

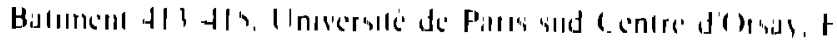
1)/f(1) (1)rads Cidex Francic

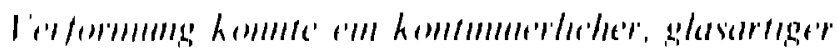

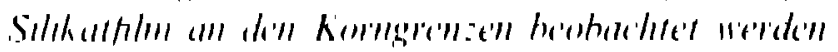

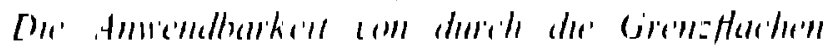

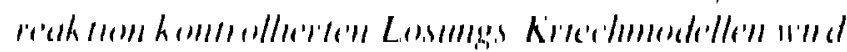

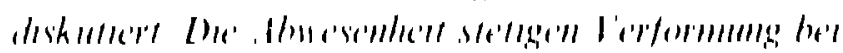

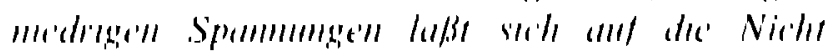

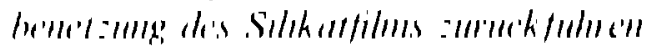

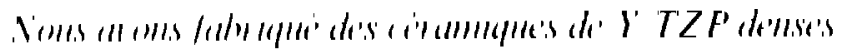

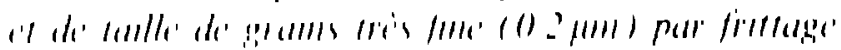

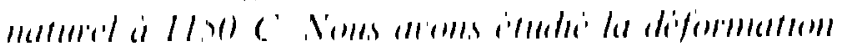

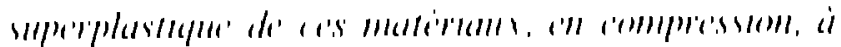

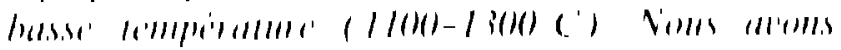

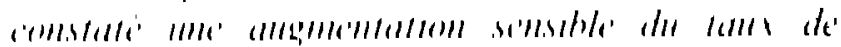

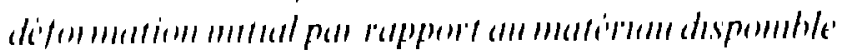

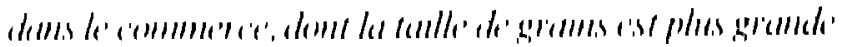

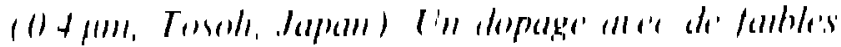

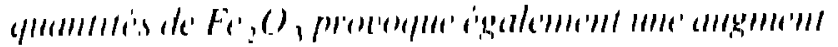

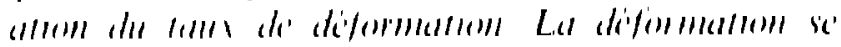

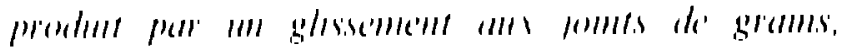

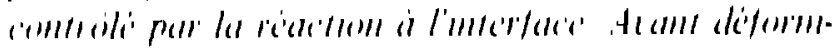

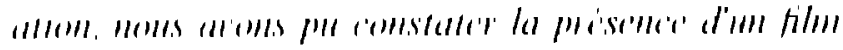

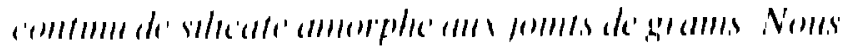

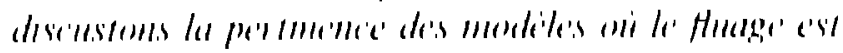

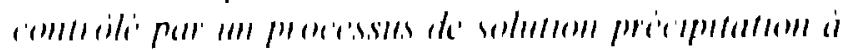

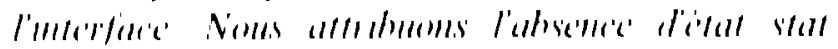

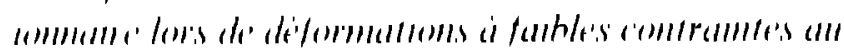

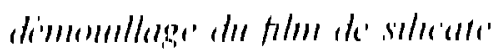

\section{InIroduction}

The potental ol tine gramed ceramics to exhibit large duchlaties al elevated temperatures was alteadv motred in 1480) from compression lests performed on magnessial ' Therealter, a tensile strain

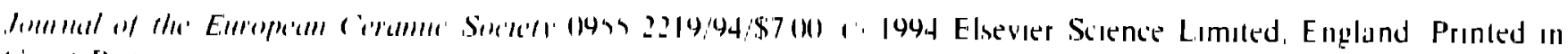
Gireal Brilallı 
above $100 \%$ was reported for a $\beta$-spodumene glass-ceramic materlal conlainang some liquad phase " However, the large $\left(170^{\circ} \%\right)$ tensile strain of 3 mol"\% $Y_{2}, O_{1}$ doped telragonal zarcoma polycrystals (3Y 'TZP) ohtained at 1450$)^{\prime \prime} \mathrm{C}$, as reported by Wakal a'l al.' in 1986, is generally regarded as the fist convincing evidence for the occurrence of superplasticity in ceramic inaterials. Since then at considerable amount of research has been perfor. med lo investggate the flow characteristic's of Y-TZP as a model material; both in tension and in compression The most important results can bo fiund in recent reviews t, "It has hecome clear that a very tine gialn saze $(-1, \mu \mathrm{m})$ leads (o) the accurrence of mocrograin or structural superplasticity all elevated temperatures in ceramic materals, pro vided no excessive dynamci grann growth occurs. This is similar lo the How behaviour ol' superplastic alloys with a gram size smaller than I() $\mu \mathrm{m}$

The large tensile ductilites of this classol ceramic materials offer the excillng possihilaty to use superplastc lormong, techmlques Io fabricate complex shapes with gond domensional control. A variely of superplastic formong, lechniquest ${ }^{-4}$ have now been successtully applied to both single-phase and composile ceramics To make superplastic forming economically attractive high stram rates at prelerably low temperatures are required

The high temperallure deformatom behaviour of cetamics is generally characterized in terms of the phenomenological how law

$$
\therefore=4 \operatorname{tex}(-() R T) \frac{\pi^{n}}{d r}
$$

where $a^{2}$ is the (axtal) stram rate, it a numerical constant. $\sigma$ the applied stress, $"$ the stress exponent, $Q$ the apparent activation energy, $d$ the grain size, $p$ the grain size exponent and $R T$ has its usual meaning The mechamsms operalong during supes plastic fow are identified by determination of the values lor the creep paramelers $n, p$ and $Q$ logether wilh microstructural observaltons, such as grain morphology and dislocalion substructures

The research on Y.T'ZP materials has almost exclusively heen focused on comnercially available malterials (mainly supplied by T'ossoh (Co or Dalıchı Nippon Kigenso Kagaku Kogyo (o... Japan). These commercial materials cun be sintered as recelved Io) (nearly) full densily at temperatures starting from $140(0)$, leuding to a minımum gramn size of (1) $3 / \mathrm{mm}$. Only by hot pressing" or elaborate collondal processing " can the sontering lemperature be lowered to $1250-13(0)$ "' $($ ', resultang in a decrease of the gram size (1) $(1.21-(1) .25 \mu \mathrm{m}$

In this paper it will be shown thal, by using an ultratine powder prepared by a wet chemical method, the sintering can be lowered to $11501 \mathrm{C}$ for
Y-T'Z.P. In this way a reduction of the mean grain size $1001021 \mu \mathrm{m}$ by normal free sintering has been realized. The reproducibility of the used synthesis method is such that this result can he obtalned in a roulıne like way with all powder balches. It has been invesligated whether use of Y TZP materials fiabricaled vad this route allows a lowering of the superplastic lorming temperature (defined as the minmum temperalure required for oblanning strain rales _ $1\left(0^{-4} \mathrm{~s}^{-1}\right.$ under $2(1 \mathrm{MPa}$ ) or alternatively a reducton ol' forming tones due (1) an increase in strann rates, compared to commercially avalable materals Furthermore, it has been examined whether the delormation rates of these materials can be lurther enhanced by adding a small amount of $\mathrm{Fe}_{2}(\mathrm{O}$, as a solld solution additive

'The results of compression tests performed on these materlals are described here and compared with earlier results ohlained by Nauer \& Carry' on Tosoh materials. The gram houndary chemistry has heell lound to have a strong impact on the macroscopte deformation behaviour. Gram boundaries of $Y$.TZP before and alter superplastic compression have been intensively studied using $X$ ray photoelectron spectroscopy (XPS), impedance spectroscopy (IS). scanning Auger moroscopy (SAM) and trinsmission electron microscopy (TEM). The mall resilts of this gramn houndary analysis, which are of importance ill order 10 understand the superplastic fow characleristics, are given here. The liull analysis will be reported elsewhere 1:

\section{Experimental Procedure}

Nanocrystalline (erystallate size $x \mathrm{~nm}$ ) zirconia powders doped with 26 mol $\% \mathrm{Y}_{2} \mathrm{O}$, were prepared by a gel precipitation lechnique, using metal chlorides as precursur chemicals. This so-called chloride method yields very sinter-reactive powders with a low degree of agglomeration Delanls of this synthesis methond an be linund elsewhere. " 'Three "chloride' powder balches (codenames Chl, where , is 1,2 or 3) were investigated, differing only in residual inpurity content (as analysed by Hameless AAS). The impurity content of these (Chl powder balches and of a 3 mol" $\%$ yllria-stabilized 'Tosoh powder (codename TS $3 / 2^{1+}$ ) is given in Table I. A part of powder batch Chl 3 has been doped with $06 \mathrm{~mol} \% \mathrm{FeO}_{1}$, A chemisorption technique utiliz. ing, iron acetylacetonate $\left(\mathrm{FeC}_{1}, \mathrm{H}_{2}, \mathrm{O}_{n}\right)$ was employed lo oblain a hornogeneous dispersion of iron. Delails of this procedure have been described in Rel 15.

Green compacts were prepared by cold isostatic compaction in two steps (100) MPa, followed by 4(0) MPa) Dilatumetry (Nelzsch 402E dilatometer) 
Table I. Impurily conleral (w/" ") ol the powder halches

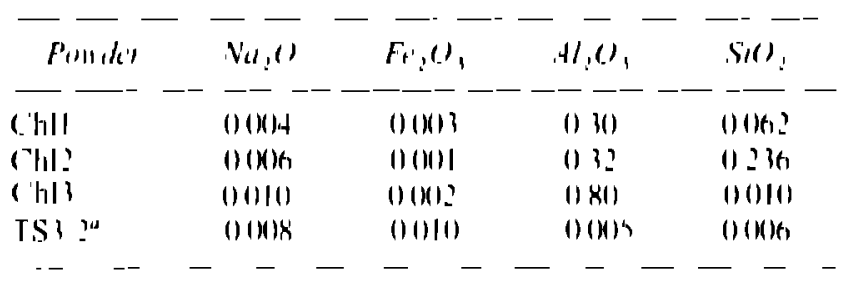

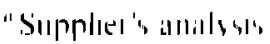

wils used to compare the densification kinelic's of the chloride powders with those supplied by Tosoh. Chlonde samples lor compression tests all received a

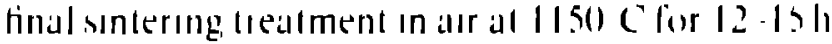
(heallong and coolmg rate I20) (c:h). followed by machionng Specinnens of chll and Chl 2 were first presintered al $11(0)$ ' C for $12 \mathrm{~h}$.

Unarial compression look place in alr al

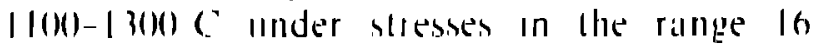
120) MPa Tests were terminuled at true strams of 114 lo alorid mon unlaxial siresses and froctuon condillonss. Axial displacements were measured Internally durmy the tests Specimen temperaltures were mononoted hy id thermocouple localed on the Imonedate vicullat of the deformang specimens

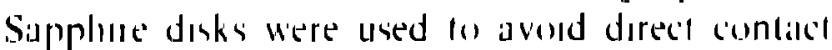
helween specimell and Sic postoms Constant stress experintellls were performed on rectangular 17 * 7 . 21 mm specimens usugg, an Instron testong, mashome Specomems were lealled all lo(k) (:h. fol lowed hy heatlong al $15(0)$ (5'h to the destled end temperature lobllg such hogh heatmg raltes prevents microstructual changes from occurrmg doumg leallme Addollonal conslant load experments wero perlinmed on cyllndrical silmples (henglı 13 mm. diam elet

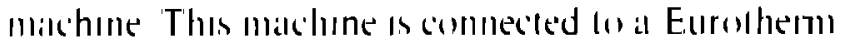
F'IC'S II controller and a computer equipped will lhe Eurohterm soltware package ESP (version 322 ) III a master-slave contiguratan A ciacciade control ivslem (Inaster locad. slave. hydraula pressiare) enables the pertormance of constiant load expert ments The response of the hydralulic system was low slou lo perlorm constiant stress experiments Speco. merns compressed on the Elaltec machine were healled

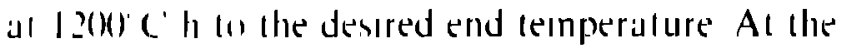
end of all compression tests the lond was youckly removed and sianples were cooled down nalurally.

Compression of milterials Chll, Chl2 and TS $3 / 2$ was perlormed with the Instann machone, while the purce and aron doped Chl3 malterial was malnaly compressed in the Elatec machone Comparahle lessulls wele ohtaned with hoth machones durng creep tests perlonmed on the Chl 3 maleralal, mdicat arge, that identacial testang condllouns could be imposed with hoth inachines The inost impoitant characteristics of salmples used for compression tests are given in Table?
'Table 2. Sirntering |reatment and characteristics of malerals used linr compression lesis

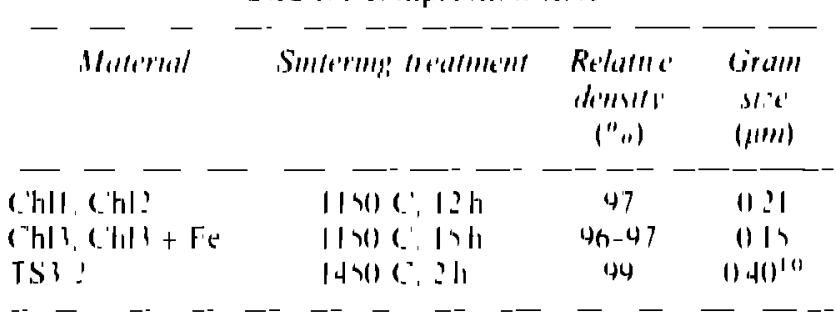

The load and displacement readings were conver led Inlo true stress and straln rate dala. Stress exponents were deduced from strain rates under various stresses using eqn (l) or from individual utress fumpo using

$$
\left.n=\log , \varepsilon_{1}, r_{2}\right)\left(\pi_{1}, \sigma,\right)_{1}^{\prime}
$$

where $z$ is the straln latle al flow stress $\pi_{1}$ and $k_{2}$ is the stran rale all how stress $a$. The values from both technlyues were in good agreement with each other A single specomen was olten used for stram rale determinations under several increasing flow stesses

Densilles were measuled by the Archimedes lechnique (In $\mathrm{H}_{\mathrm{g}}$ ). Cirain sizes (d) were delermmed hy the lineal intercept rechntque l'rom SEM (Holach Sx(o)) mucographs of polsshed, thermally exched cuts using $d=156 L$, where $L$ is the average lineal Intercept

[eetuls al the experimental procedule to characIerize graln boundaries of the Cha materials assing XPS. SAM, IS and TEM are given in Rel'. 12.

\section{Resulis}

\subsection{Undoped Y-TZP}

il I Sintrim! kintillis

The relative shronkage during, heating at I20 $\mathrm{C} / \mathrm{h}$ (1) 1450 ( $C$, als measured by dilatometry, of a $(\mathrm{Chl}$

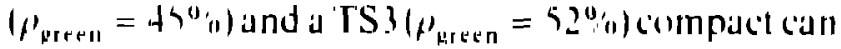
he seen in Fig I. A significant difference in

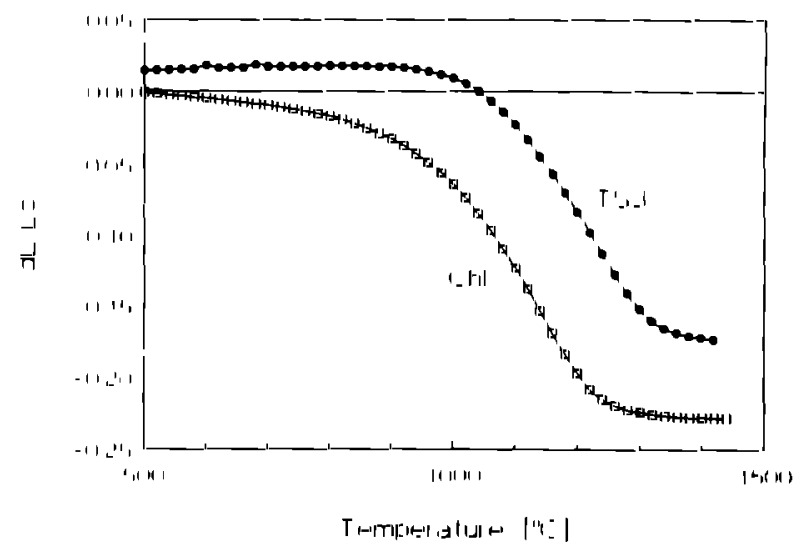

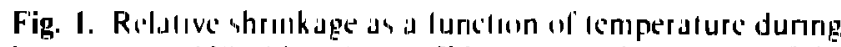

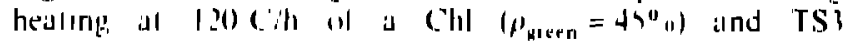

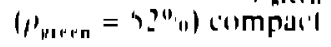


sinterability is found: whereas the TS 3 sample only starts densilying above $9500^{\prime} \mathrm{C}$, the $\mathrm{Chl}$ specimen densities already starlang from $5(0)(\mathrm{C}$. The maxImum shrinkige rale equals $3 \times 10^{-4} \mathrm{~s}^{-1}$ lor both specimens fequivalent 10 a densificution rate of

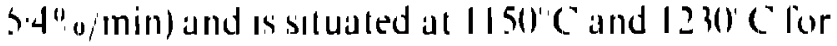
the Chl and the TS. specimen, respectively. Final densiles equal $97-98$ " "for hoth materals after this sintering schedule. 'The densificatoon of' all three inverligated Chl malealals was simalar.

The Chl specimen reached $96-48 \%$ of of the theorelcual densily $\left.(6.1) \mathrm{kg} / \mathrm{cm}^{\prime}\right)$ alter isothermal sintermg at 1150$)^{\circ}$ during $10 \mathrm{~h}$ (heating rate $120(\mathrm{C} / \mathrm{h})$ By contrast, TS 3 samples only reached $73^{\circ}$ " aller the salme heat trealment

\section{1 ' Compresistull lests}

Strall rates are shown als a funcloon of true strain m Fig 2 for all three onvestlgated $\mathrm{Chl}$ malertals during. compression at $1250-13001$ ' $\mathrm{C}$ under a conslant stress of $20 \mathrm{MPa}$ (with stress jumps ? $1=16 \mathrm{MPa}$ and $20=24 \mathrm{MPa}$ lo determone the stress exponent, the result of which will be mentoned later) The most important obselvaton of Fig. I is that no steudy stale is observed, stlice the sltam rate is decreasing contonuously lior all there malerials. A simalar hehaviour has been observed at II(x) and $I 2(x) C$ under constiant stresses of $2(1)-40 \mathrm{MPa}$. During compression at 12001 (" under hogher stresises (80), 12() $\mathrm{MPa}$ ) the stran rale temalns essentlally const ant. This apparent work hardenong canmol be explanned on the basis of gram growth (see Section 31 3), hut is relaled to changes on the gia an boundary chemostry as will be doscussed in Sectuon 4.4

In the remalnmeg part of thos sectlon altenton will be lickised on the flow hehuvour of inderials ('hll and Chl2 and It will be compared to that al the conmercial malerial TS3:2

Intlal straln rates (al stranns:-1103) ol (Chll and Chl2 under 20 MPa are slown on Fig., 3 an a function of inverse temperature Steady-state stran Iates of material TS $3: 2$ are also inserted in this tigure At I3(10) (" the Chl materals deform intlally at stain

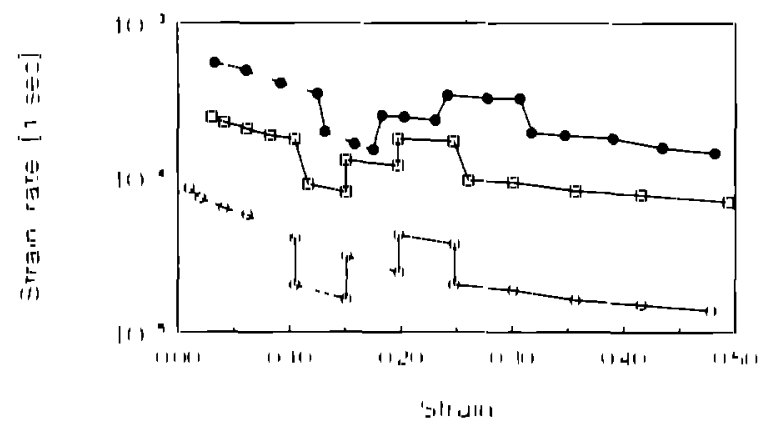

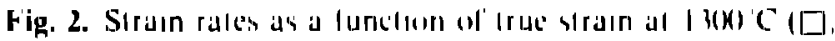

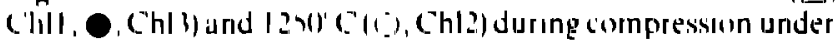
a consianl stress oll $20 \mathrm{MPal}$ (Inlerrupled hy siress jumps $20=16$ and $2(1)=24$ MPa lo delermine lhe stress expuneril)

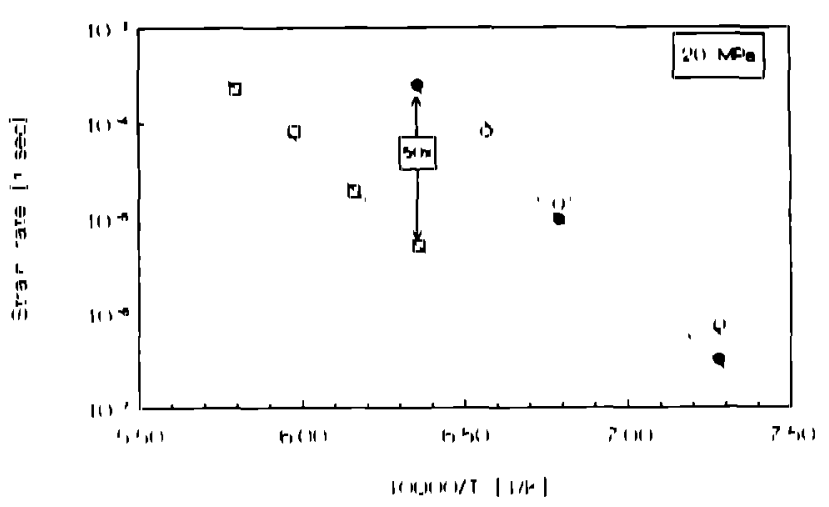

Fig. 3. Temiperalure dependerice ol strant rales under $20 \mathrm{MPa}$

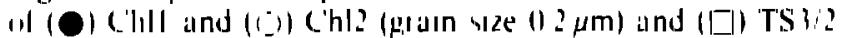

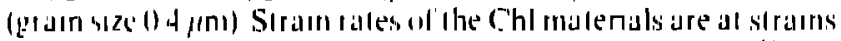
- 0103, whole those "if TS 3:2 arre sleadv slate values."

rates in limes laster than observed for the TS $3 / 2$ materal The apparent activation energies al 20) MPa as determined from the slope of these curves equal $58(0 \pm 2(1) .1,1444 \mathrm{~h} \pm 13$ and 540$) \pm 42 \mathrm{~kJ} / \mathrm{mol}$ lin TS3/2, Chll and (hhl2, respeclively. The temperdlure dependence of the deformalson rate is thus simalar for all three malterials

Figure tillustrates the variationolit'stram a ate with stress observed durmg compression under stresses increasing l'rom 20 10 120 MPa all 1200 C $^{\circ}$ of a Chll and (Chl specimen. Slightly higher stram rates are wherved lin material (Chl2, which has a higher impurily content than Chll (see Tahle 1). A stress ol ()-6) MPa is required to ohlann strain rates larger than $10^{-4} s^{-1}$ all this lemperature The slless exponent calculated from the slope of these curves equals 2 2-2 3 for both materlals Sudden stress

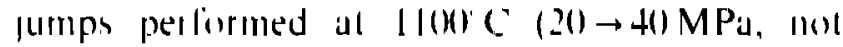
showil) and $1300(\mathrm{C})(16-2)-2+\mathrm{MPal}$, sete Fig. 2) vield identical values (21-22) lion the stress exponent.

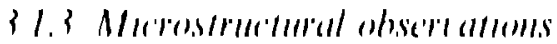

Examinalion of the mocrostructure by SEM alfer deformation reveals that the grams rentain equaxed at true strallns of (1).5() al all investigated temperalorres This observatoon already shows that gram

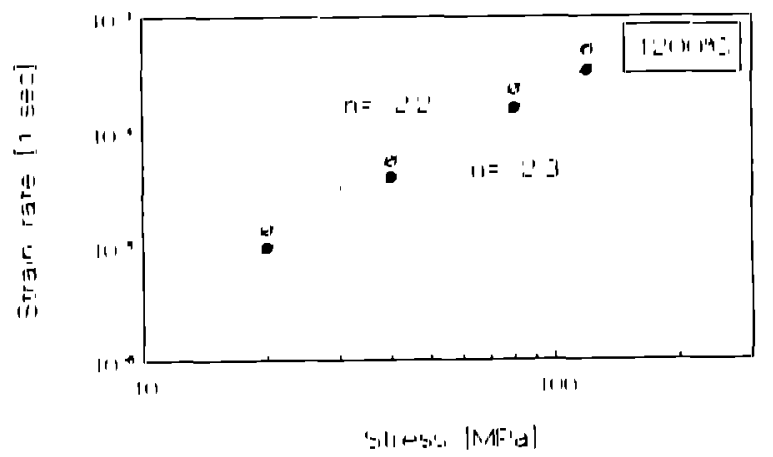

Fig. 4. Stress dependence ol the siran rate ol a (O) Chll and (i) (Chlz specimen all Izom)"C during compression under increalsing, "Mresses of $2(1-120) \mathrm{MPa}$ Siran rates ohserved immediately alter coinpletion of' a slress jump have heen used here 
houndary sliding is the dominant How mechanısm. ${ }^{\text {th }}$ Although the final deformation temperature was always siluated above the sintering temperature 11140 () ( ) the gram size remanned yulte stahle even at the highe'st delormation temperature (I 3(x) C) For

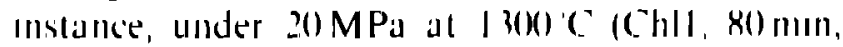

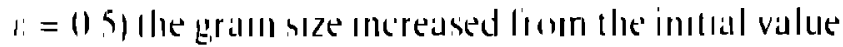

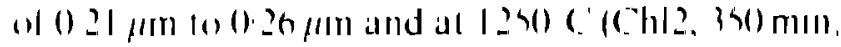

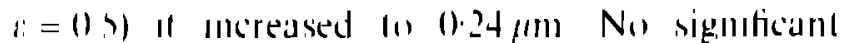
dafference hals been lound hel weell samples thal were connpressed and lhose which were subpected to the salme heal treatment wilhoul beeng compressed

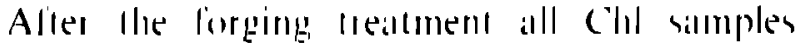
showed all increase all dembly $1098-44 ; "$ "Silmples which wete subpected on the same hoal treatment hul Ilor compressed, slowwed no or vely lithle mciedse in densily Residal porosily caln lhus he removed hy the lormente opelatton thedl

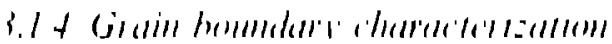

Giram buundalles mo the Chll and (hla materals hefore and after compresson were characterized hy TEM. XPS. SAM and IS. Alter sintering al I/ 190 ( ) llan (4 I0Ä) contolmous laver ol an amorphous phise wals obselved bo TEM allong the grain boundartes. XPS and SAM measurements showed

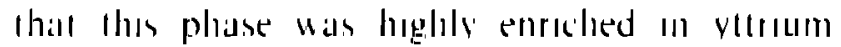
Silcon was detected by XPS and the hinding energy andralled that ol wals present as a slacate Although powder balch chle contains thee lomes as much

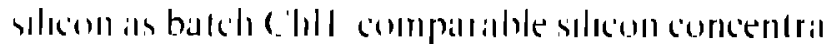
molle vere ahsorved all the gram boundarles

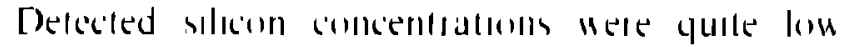
(S) Zr Iallon less lhall (1)(1) Other malln impuralles

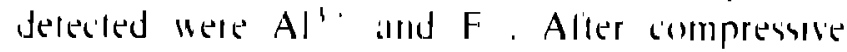
delormallon some geam boundaries were no longer corered by the amorphous phase als ohserved hy TEM Whach liactorla ol ale gralun boundarles is 'ileall hals mol heen delermmed XPS gave direcel pront and is indered prool that the aterage

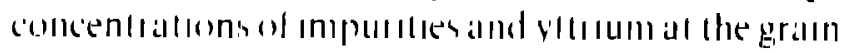
boundarles decreased illea compressive detorm allon. Than dectease became slowger wollo mereasing 4lews

\subsection{Compression of $\mathrm{Fe}_{2} \mathrm{O}_{1}$-doped $\mathrm{Y}$-TZZP}

strann tales als a functionn of appled stress 12) I(x) MPall, als evaluated from constant load experments, alre shown an Fig. 5 at I $2(x)$ and $I 3(0) C^{\circ}$ lol the undoped ('hl/ 3 material and al $120($ C C for (1hmol" "Fe(), , doped ('hl, An enhancement in "Iralln rate by al lactor of $4-6$ compared to the undoped malterlit is ohserved al I Iorl'(' upon

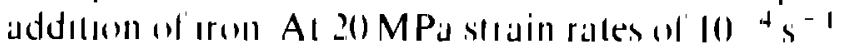
alle whserved lor thos inaterial, whole $\left.10^{-1}\right)^{-1}$ is reached under $70 \mathrm{MPal}$

The stress exponent calculated from the slope of

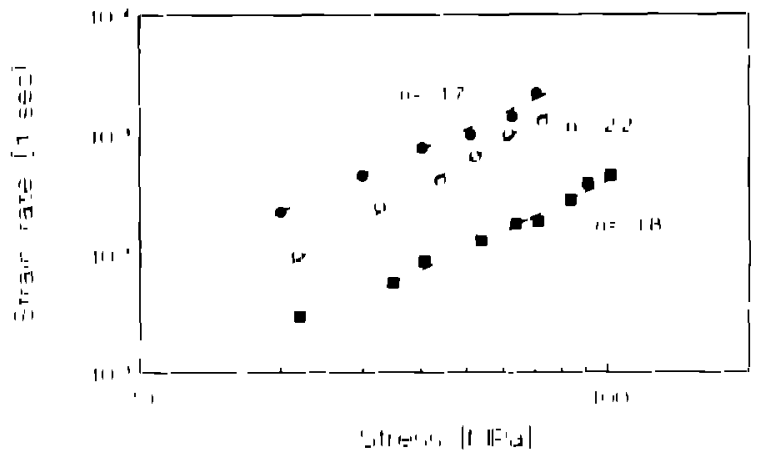

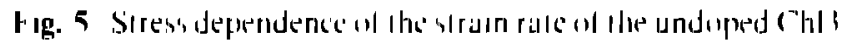

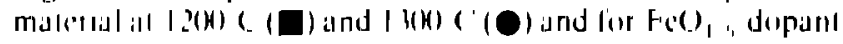

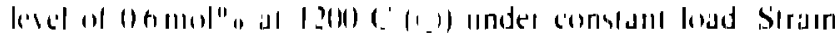

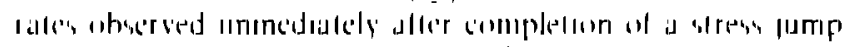

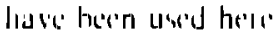

the c'urves in Fil. 4 equals 1.7- 8 for undwped $\mathrm{Ch}_{1} 3$ and 2 ? lor the iron doped chl 3 material The stress expontent calculated firm the individual stress

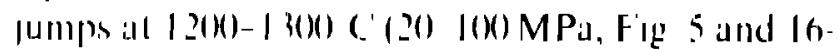

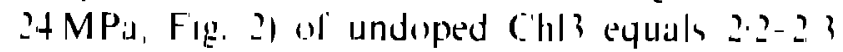
The sless dependencesol the strann rate thus remians unchianged hy the addalom of Iroll

\section{Discussion}

\section{I Deformation map}

Recencly, Niluer \& Carrotit proposed a gram size versus stess deformation map lor ?Y TZP hatch TS2) all I 30() (' Thus deformallon map is connsidered bulad lon Y TZP materlals with a relatively high

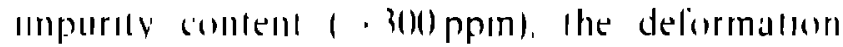
behaviour of purer matemals being markedly difierent " comsidering the impurity contents of the ('lal malsolals(Tahle l) the deformatlon map should

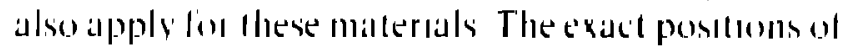
the houndillles helween the various deformation medhinmsme however depend on the nallure and amounl al' residual inipurilles, als will be discussed later. The deformatlon map has been recalculated lin I Ion C. and is shown on Fig. to The villues of the creep pilramelers an gelven m Rel' 14, are mserted in

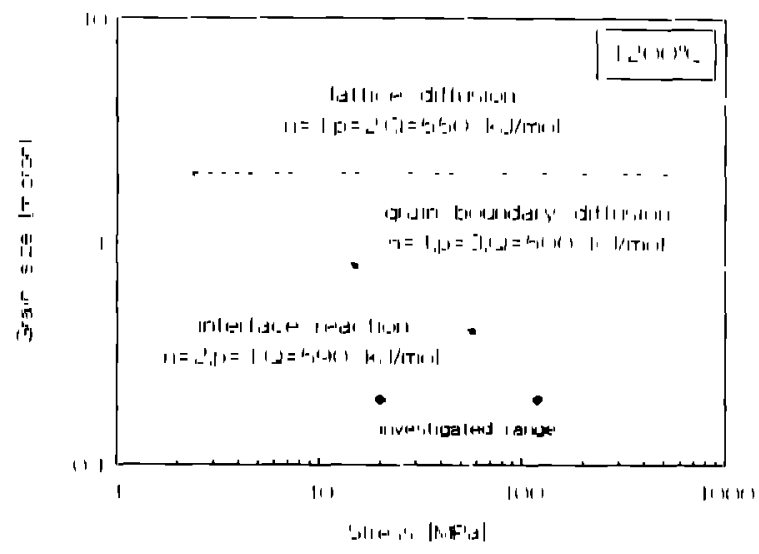

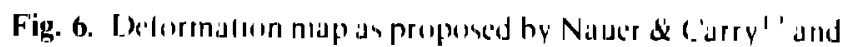
recialculisled here lor I I (K) ( 
the different fields. It can be seen that the experimental conditions (2(1-120 MPa at $0.2 \mu \mathrm{m})$ of the tests perlormed with the Chl materlals are siluated in the interlace reaction contolled field Indeed, the creep parameter values delermined here $(1)=2$, $\varepsilon=54(1)-596 \mathrm{~kJ} / \mathrm{mol})$ are in good agreement with the creep parameters of Nauer \& Carry for interlace reaction control This suggests that creep of the Chl materals is interface reaction controlled under the investgyted expermental condilons A discussion of the chatracter of the interlace reaction will be given In Sectuon 4 ?

The validily of the delormatlon map is supported by the results ol varusus other researchers Wakal \& Nagonoly observed a transilion from diffusion control lo interfice reacton control at $14501 C^{\circ}$ and stresses below soMPa, when the gram size wals lowered from $1.4100 .55 \mu \mathrm{m}$. Hwang \& (hen ${ }^{111}$ pellormed compression tests at $110(1)-1250)^{2}$ in the stress range $6(1)-8(0) M P$ al on a $2 Y^{\prime}-T Z P$ materal with a grain size eyual (1) $1121 \mu \mathrm{m}$. At 1179 ( ) they delermmed the stless exponent to be equal $101 \cdot 6 \mathrm{mll}$ lhe stress range $1.5(1)-70) \mathrm{MPa}$ and the gram size exponent $10=1(()) \mathrm{MPa})$ was 27 This cleally indicates gra ain boundarv difluson control. although part of their stress range is stlualed in the interlicte reactuon tield on the deformation map shown in Fig. b. Amana if al." ohserved a Iransillonl Irom interlace reactoon to graln boundary dolfusion control above lo MPa al I $3010 \mathrm{C}$ in a $3 Y-T Z P$ material $(d=(1.60 \mu \mathrm{m})$. Thus value of the transiton stress is slighily lower than the one predicted hy the deformation map. It is furthermore worth mentonning that a transition from grain houndaly difiuston 10) lattice diflusion control has recently heen

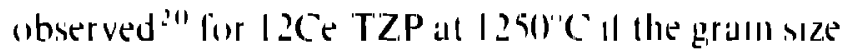
becomes lalger than $2 \mu \mathrm{m}$. II good agreement with the detormatton map.

Interlace reaction controlled and gram boundary diflusion controlled gran boundary slidang are actung in sertes and the observed strann rate fican be wrilten as:"

$$
1 / t=1 / h_{11}+1 / t_{\text {phod }}
$$

where $i_{11}$ and $i_{\text {plid }}$ are the stram rate for respectively the interliace reacion controlled and the gram boundary diffusion controlled inechanism. The slowest process delermunes the deformation rale It hals been shown from experiments that stram rales of Y TZP are much inore sensilive (1) the impurity content in the interface reactuon controlled than in the grain houndary diffusion controlled field " (the reasons lor thas phenomenon are not yel clear) Hagher strain rates are observed for more impure materials The transition from interface reaction (1) grain boundary diflusion control is therefore influenced by the residual impurity content and this transition will occur al lower stresses for more impure malerials The nature and amount of unpuritles will thus not influence the general form of the deformation map of "impure" Y-TZP proposed by Nauer \& Carry. but will influence the exact pusitions of the boundaries between the diflerent fields.

\subsection{Strain rate enhancement of $\mathrm{Chl}$ in comparison with TS 3 materials}

The grain size exponent $p$ equals I for the TS $3 / 2$ material in the inlerface reaction control tield ${ }^{14,1}{ }^{7}$ If the strain rates of the Tosoh malterlal are recall. culated (using, eqn (1) with $p=1$ ) for the same grain size $(1)-2 \mu \mathrm{m})$ as the $\mathrm{Chl}$ material, an increase in imital strain rate by a lacelor 26 is still lound for the chloride (Chll, (Chl2) materials compared to the TS3/2 malerial. It should be noted that strain rates of a second Tusoh maleral (TS $3 / /^{\prime \prime}$ ) with a higher $\mathrm{Al},(0$, impurity content were faster by a lactor of 5 compared to the TS3/2 material for an identical grain size. Clearly, the grain size is nol the only liactor responsihle for the observed differences in strain rates This difference can arise from the difierent amounts ol impurities in the startung powders (see Table 11 as well as from the diflerence in sintermg. temperature of the investigated inaterials. It is helieved that in materials sintered at 11.50 ( $C$ (as is the case for the (Chl mulerials) the segregation of impurities lo the gram boundarles is much stronger than in materials sintered at higher temperatures $(14(0)-1450)$, as is the case for the Tosoh malerials) Evidence lor this hypothesis can be lound in the work of Biddwal \& Hughes," who used XPS and IS In characterize the gralln boundally network in cubic $\mathrm{ZrO},-Y^{\prime}()_{1}$ and observed that an impurity silicale phase, wellong the gram bonndarles at low tempera lures, starts to dewet and migrate to the external surlace helween 1350 and 1450$)^{\prime \prime C}$ Furlhermore, Chen at al" found by IS that the gram boundary resistivily per unit surlace area of the grann houndarles $\left(R_{a, p}\right)$ ol the Chl materlals heal treated at temperalures ahove 1150$)^{\prime \prime} \mathrm{C}$ decreases conlınuously with temperature, indicating a decrease of the impurity concentratoons at the grain boundares.

\subsection{Character of the interlace reaction, pressure-solution creep}

It has been shown for the Chl inateraals as well as for the TS $3 / 2$ material't that deformation is interlace reaction controlled in the low stress regime (the widlh of which depending on gram size, lemperalure and impurity content), characterized by a stress exponent equal to 2 The grain size exponent equals I in this regine 11.17 A simular $\sigma^{2} / d$ dependence of the straln ralle has also been observed by Cannon e't al. ${ }^{24}$ for alumina The character of the interface 
reacion and the role of the glassy intergranular film durng creep will now be discussed in grealer detall

An amorphous phase is present at the gram houndaries as a contınuous film having a thickne'ss less than I nm or I 5-2 nm on the Chl and the TS 3 " malerials, respectively Thas film is presumably liculd-like al the temperature of deformatlon and is able lo supporl moderate nurmal stresses : "It has been reported on the lateridture thall the addalon of up

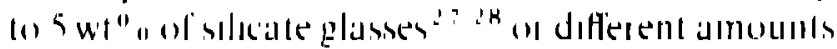

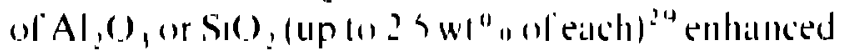
llee strain rates, hat did mol change the stress exponent. which remanted equal to? In the cited onvestigattons all amorphous phase was present as a than I 2nm film ill the grann boundartes and the excess amorphous phase was lociated al comple pounts In the present authors' experiments with the ('hl 3 malterial it hats also heen ohserved that additon of Fe, (), enhanced the stralln late withoul changeng

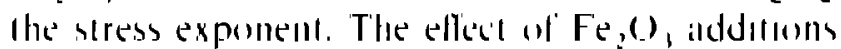
un smterme ind creepol Y' 'T'ZP is discussed on more delall elsewhere

The liquid like film present III virtually all TZPS moghi allow creep lo occur via a solutornpeciputatom mechamssm Permanent stram wonld be poosided ho switching al neghlobourng grallm durmg gram bommdars sliding. whole locial stadms durmg the sistshong event are accomodaled by a dissolullon-doffusmon-precipitalion process alt lhe graln hollndalles Theorelcal models lol

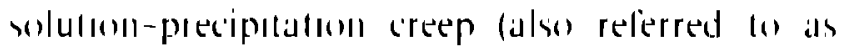
'pressure solullonl creep' in earlh science lolerature) have been developed ho several authors $31-11$ Doffusion through the liquid phase an dissolution-

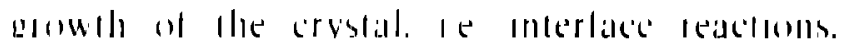

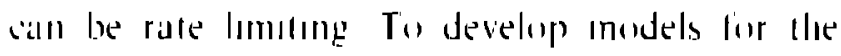

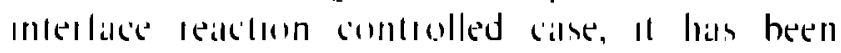
assumed that dissolution or grow hof a a crystial an an under sopersaturated solutom is andologous to the

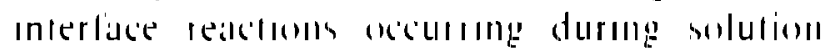

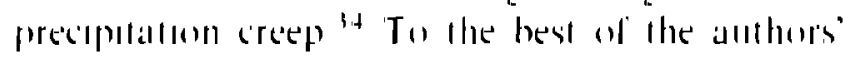
knowledge all models developed so fir have dssumed that ferowhth or dissoluteon is linearly popostomal lo the driving lorce Doumg solulon-peciplatlon creep thas droving lorse

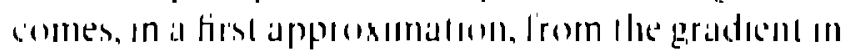
the normal tractorms along an mleslacis. The gradent equals $2 \pi \Omega d^{\text {, }}{ }^{\text {in }}$ where $\Omega$ is the molecular volume and the outher symbols have theor previrusly defined ineanme Models alssumng lonear cryslal growlh as the interlade reactom therefore all lead (o al stress exponent equal on I for the interlace teaction commolled cadse

However, avallable crystal growth theornes show that coystal growth rates are only linearly propor tounal to the driving lorese al the crystal liace is growing ahove the so-culled rougheming tempera ture or il'a spiral growth mechanism is operating on a flat live at high values of supersaturation " At small values of supersaluraton the crystal growth rate is proportlonal to the square of the driving force for spural growth als derived by Burton, Cabrera d rralnk (ciled in Ref' 34 If this crystal growlh mechanmsm would be rate lamulang during solutom-

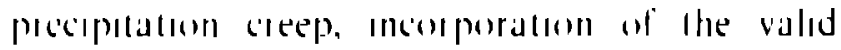
cmstal groush law anco the existing theorles for soluton -preciptaton creep leads to a $\sigma^{2}$ id de pendence of the stalla late This is indered the dependence absersed forr Y'TZP an the interfiace

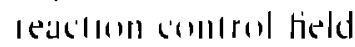

For a spiral growth mechanism the groweth rate is derectly proportlonal to the suturallon concent

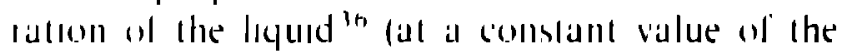
driving forces li preciputation va speral growth is rals lomilong dumlong solutoon-precopulation creep. strilln rates will scale with the soluhility oll the solld In lle liquid. The composstom al the anouphous phitse III Y' TZP will determine the solubility of zarconla in II and higher soluhilaties should the'll lead (1) hogher strain rales It has indeed hee'n observed recenty :s lon Y TZP doped with lün lypes of silcale glasses that the stram tale on the interlace reactorncontrol field is proportannal on the solubilaty

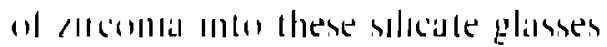

The malcouscoplc how hehidwour of Y TZP on the interlace tedcilon control hield thus seems lo tit well with presiputaton controlled solutom-precipitation creep with spulal growith as the covatal groweth mechanosm However, on the casse ol superplastic Y' TZP. the laquid him has a thackness of only a few manomelers and a spolal growll mechansm is lherefinc most unlakely heculise of geometrical reasons. TEM whorvations have indeed never revealed sich sparal structultes lo exist al the grain boundaries It is alog questomable il the avalalable

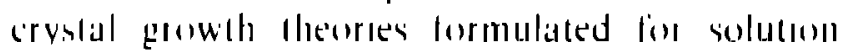
growth call be directly applied an preciptation of gerowith units oul of a liquad film al only several manometers al gran boundarles under devalory tensile stresses. If crystal growith rates in such a comstranned licjuld film would be proportonal to the squale of the driving force withoul requirang al sparal structure. thas would lead lo a model for interlace

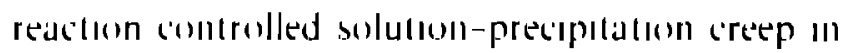
gond agreement, hoth microscopocally and macroscopscally. wilh superplistic creep of fine gralned $Y$ 'TZP an the low stress regane However, slich a crystal growth medianmsm still has an be established Most experomental studies al inluton-precipulal lan creep have been perlurmed on materials like $\mathrm{NaCl}$, " is $\mathrm{KCl}$ and sucrose, " which have a logh solubility in the liculd phase (water) The whaserved stress exponents are equal 10 I in these cilses and diflusion through the liquid phase is 
considered to be rilte limiling during creep of these inaterrals." "Creep studies of ceramics with an intentonnally 'added' intergranular licind phase 10.27 .24 is show that interlace reactions are rate lamolting and observed stress exponents are near 2. The solubility of the studied ceramies in the varouss liquad phases (silcalte melts, contanning various callons) has in general not been investigaled, hut must be quite low. considering the chemical inertness of most technical ceramics. The solubility of the solid in the liyuld phase thus seems to be a key parameter during solutoon-precipitalion creep.

The structure of the Huid contaming gram boundary of materials with a high solubility in the liquid phase is very much different from the one whserved in ceramics A dynamically stable, island-channel network with a thickness of $6(1)(\mathrm{nm}$ is lor instance observed at the gran houndaries of $\mathrm{NaCl}$ (g,rann size I(o) $-275 \mu \mathrm{m})^{34}$ delinrmed in the presence of waler, while the liculd phase in ceramic's is present as a very than film ol a lew nanometers.

Future theoretical modellang of creep of ceramic's with an intergranular liguad phase should also pay attention to the lact that the physcal propertles (viscosity, diffusivity) of' a liquad an the form of at 1-2 Im film will certannly devalte from its hulk values

\subsection{Dewetting of glassy phase during compressive deformation}

The apparenl work hardening observed for (hl materials (see Fig. 2) cannol he explained by graln growlh lsee Sectoon 31.3 and is allributed 11 progressive dewellang of the gian houndary sillaite film durıng compressive delormaloon Clarke't has formulated a force balance lor a then intergranular liquid film. Without applying an external pressure, the equilibrium thickness is determoned by the halance hetween altractive vall der Waals forces and a repulsive force, finding Its origin in a epridxial urientalion of the $\mathrm{SiO}_{4}$ tetrahedra with the grain surfaces Inserting the appropilate numerical values for the diflerent parameters in Clarke's furce balance shows lhat a compressive stress of 4 (1) MPd is required (1) remove a liquid sillcate film al elevaled lemperatures from $\mathrm{ZrO}_{2}$-liquid-ZrO, gram hound aries. Considering the large number of simplications in Clarke's theory, this value is in gond agreement with the mınımum stress of $211 \mathrm{MPa}$, where dewettung was observed in this investigiation

\section{Conclusions}

(a) Using nanocrystalline powders produced by the chloride method allows fabrication of dense Y-TZZP c'eramics with an average grum size of $(1.20) \mathrm{mm}$ by free sintering at 1150$)^{\prime} \mathrm{C}$ (I0 h).

(h) Initial strum rates of these Chl muterials during compressive deformation are enhanced hy al lickor of 50 compared to a coarser. gramed $((1.40 \mu \mathrm{m})$ commercially avalable (Tusoh Co., Jipan) Y-TZP material. This enhancement lactor decreases with increasing impurily content of the commercial material

(c) Under the investigated experimental condolions (IIO)(-1300) C, It-20) MPa) deformatlon of these Chl materials occurs via interficce reaction controlled grain boundary sliding, in gond agrement with the delornatorn mup proposed by Nauer \& Carry

(d) The observed $\sigma^{2} / d$ dependence of the strain rate in the interlace reaction control field can be predicted fiom solution precipitation creep models, if the rale lomilung step is precipitation occurring via a mechanism for which the growth ralle depends on the square of the driving lorce. However, alvalable crystal growth theories developed for growth from a bulk mother phase do not provide al IIon linear mechansism which seems likely for precopitalomen from a liquad contaned in a 1-2 nom thick intergranular film.

(e) Additonn of $(1.6 \mathrm{~mol} \%$ Fe(O), leads 10 a furlher enhancement of the stran rates of $Y$. TZ.P hy al lickor of 4- 6 , whle the stress exponethr remains identical to 2 At $12(0)(0$ stlalm Iales of $10^{-1} s^{-1}$ are oblanned all $a=$ $70 \mathrm{MPa}$ with this material

\section{Acknowledgements}

Akzo Chemicals B.V is ack nowledged for financial supporl of this inveslagalın. Frank Hartgers and Rente Olde Scholtenhuss are acknowledged for performıng the creep tests on the Chl.3 material, Joop Snovenbos lor machining and polishıng, Hans Weber for impurity analysis and Mare Smithers for SEM observations

\section{References}

1 Crampon, J \& Excalg, B, Mcchiantcal properles, al' hne gramed migrrestllm axide a large compressive strams

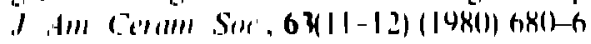

2 Wang, J \& Ras, R. Mechanmsm ol' superplastic fow in a

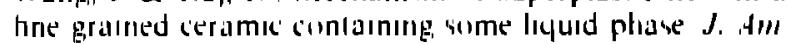
Cin am Sin, 67(6) (198.4) 194-4119

3 Waku, F, Sakaguchi, S \& Malsuno, Y, Superplasilcoly ol

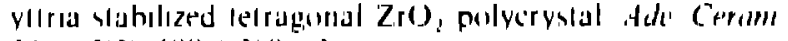
Alat, I( 3) (1486) 289-6)

4 C'hen, I W \& Xue, L. A, Developmenl of superplastic

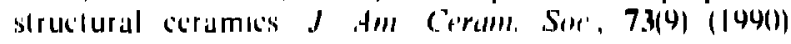
2784.604 


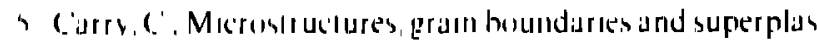

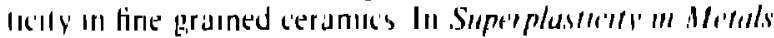

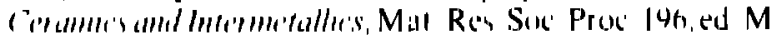
Mavo, I Waldsworth, A k Mukhergee \& M Kohayashi Maltertids Reseurch Socielv Pillshurgh, PA, 1990) PF $31\} 23$

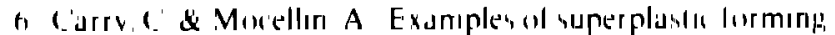

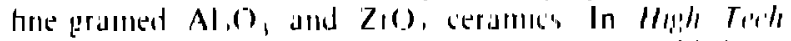

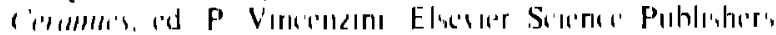

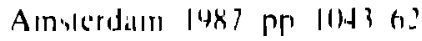

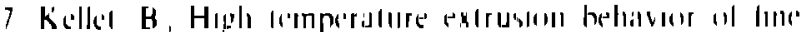

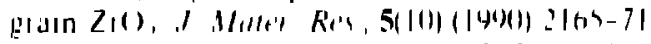

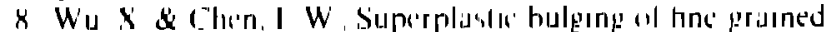

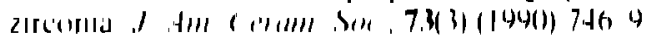

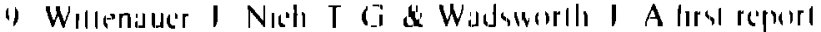

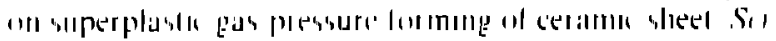

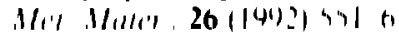

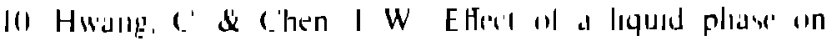

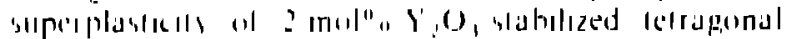

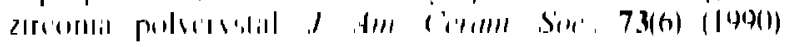

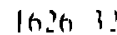

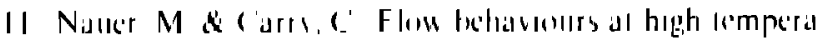

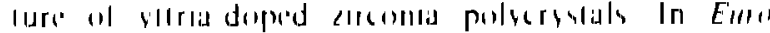

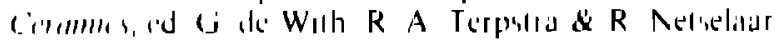

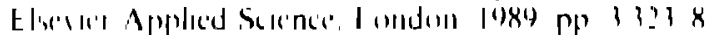

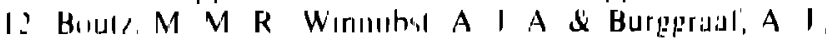

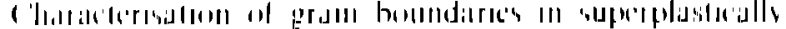

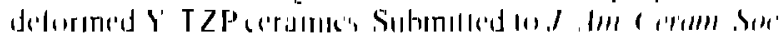

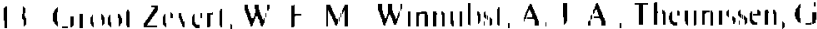

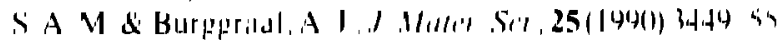

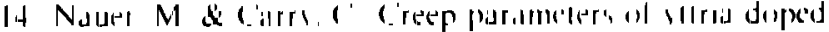

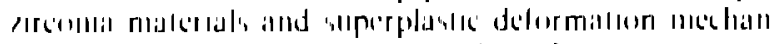

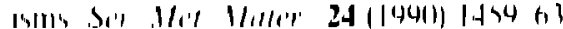

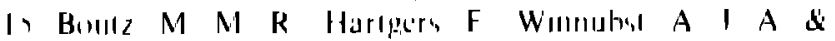

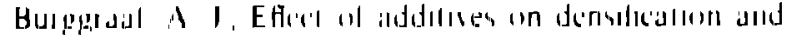

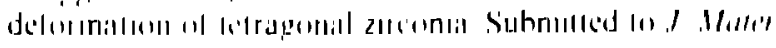
ShI

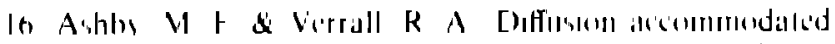

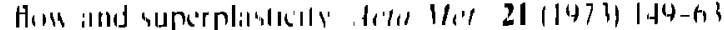

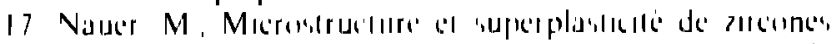

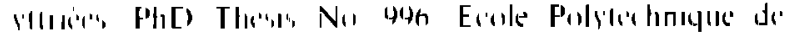

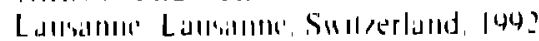

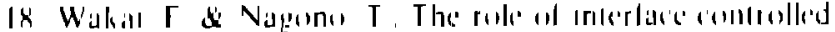

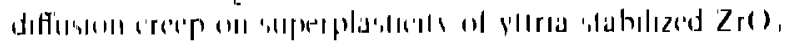

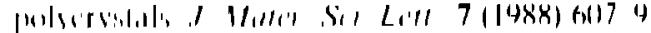

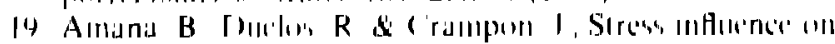

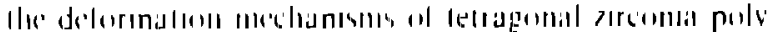

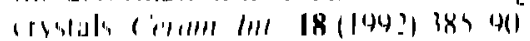

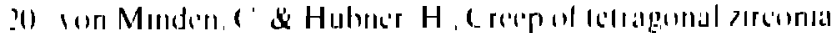

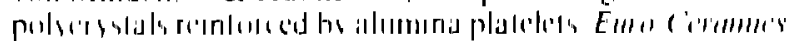

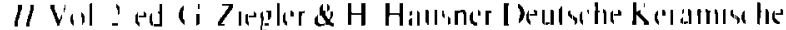

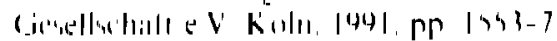

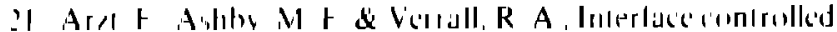

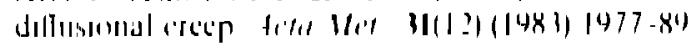

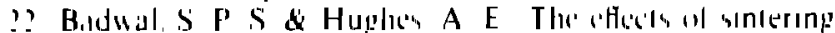

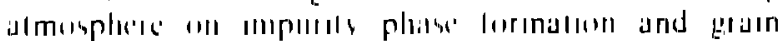

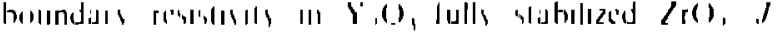

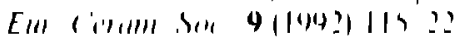

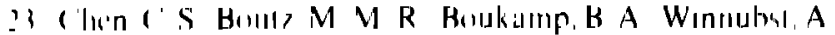

I A \& Burggraul, A I, The electrcial chariacterizallon of

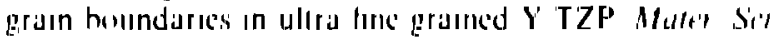
Eng i 168 (194) $1331-4$

it Cunmon, R M, Rlondes, W H \& Heucr, A H, Plasll

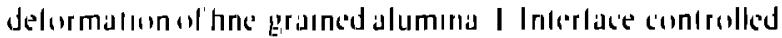

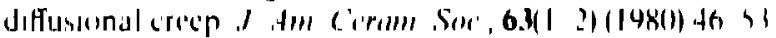

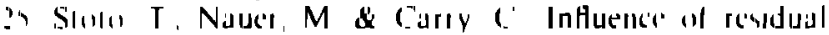

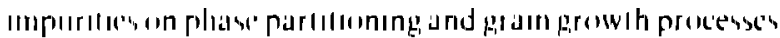

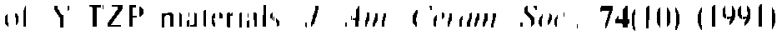
inl" ?l

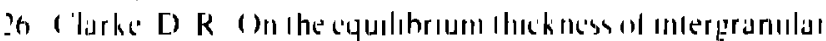

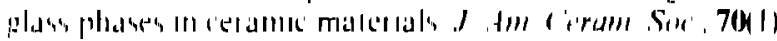
$11487119 ? 2$

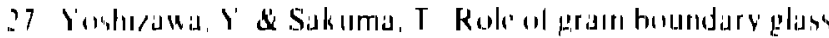

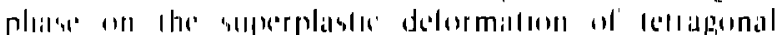

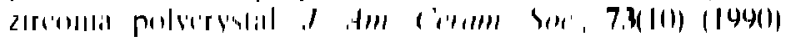
$3(16,9-73$

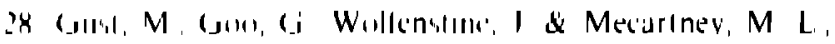

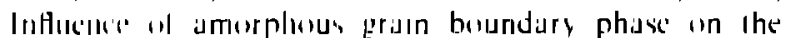

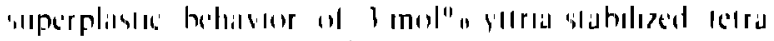

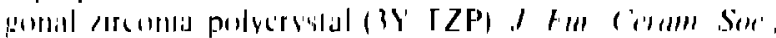
7617) 11443|| $6 x^{\prime} 1-401$

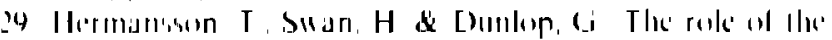

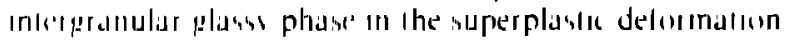

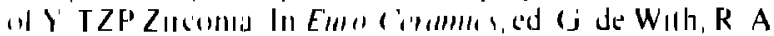

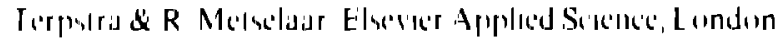
14849

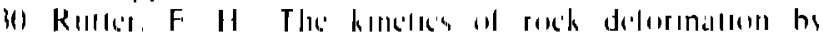

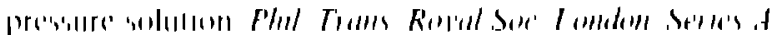
$281(14761) \geq 11314$

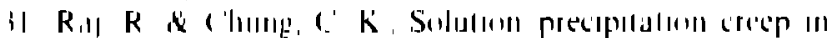

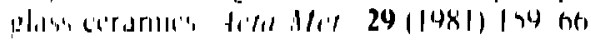

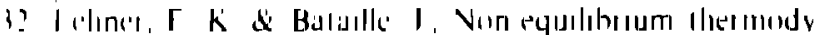

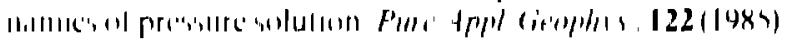
is

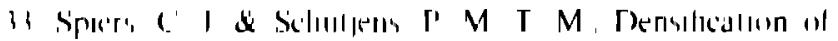

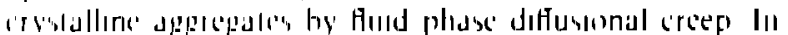

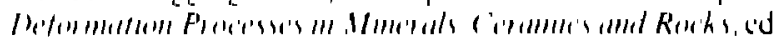

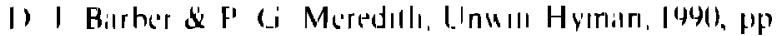
$14,4-4$

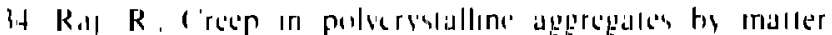

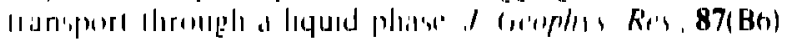
(I) 5 ?) +7114

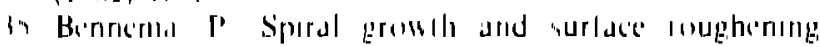

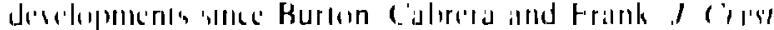
$(1,1) 116,69(198+1) 18:-4) 7$

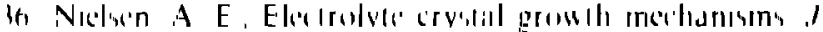
(111) $111111,6,67(148,4) 289-311$

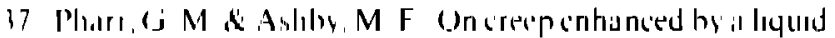

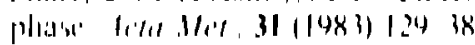

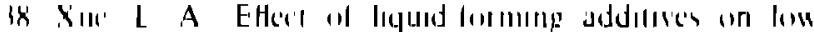

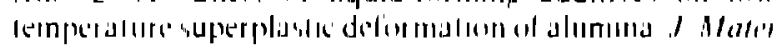

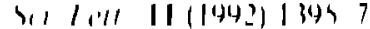

39 Sormer,

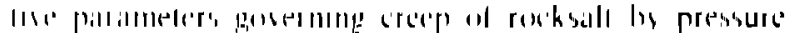

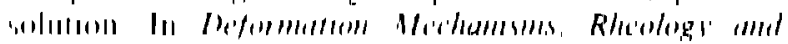

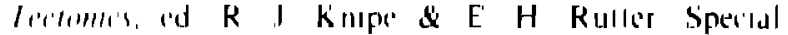

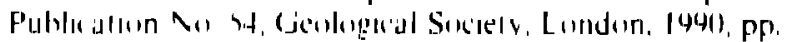
:19:7 